\title{
Effectiveness of Aerobic Exercises in Obesity Cases Pertamina MOR IV Semarang Employees
}

\author{
Hadi $^{1}$, Fajar Awang Irawan ${ }^{2}$, Syahru Romadhoni ${ }^{3}$, Tommy Soenyoto ${ }^{4}$, Dhias Fajar Widya \\ Permana $^{5}$, Mirza Arif Ma'dum ${ }^{6}$ \\ \{hadi_pabbsi@mail.unnes.ac.id ${ }^{1}$, fajarawang@mail.unnes.ac.id ${ }^{2}$, syahru_fik@mail.unnes.ac.id $\left.{ }^{3}\right\}$ \\ Faculty of Sports Science, Universitas Negeri Semarang, Semarang, Indonesia ${ }^{1,2,3}$
}

\begin{abstract}
The purpose of this study was to determine the effectiveness of aerobic exercise in losing weight and maintaining the health of Pertamina MOR IV Semarang employees. The method used in this research is descriptive quantitative. The total number of respondents who participated was 44 people provided that all respondents were internal employees of Pertamina MOR IV Semarang and were willing to be part of this research, indicated by completing the willingness sheet to be a participant. The instrument used was a physical condition test using the Tecumseh test report, aerobic exercise, and jogging. The results of this study found that 11 people $(25 \%)$ were effectively able to lose weight and maintain health. 19 people (43.2\%) were able to lose weight regularly, and 14 people $(31.8 \%)$ were able to maintain their normal condition. Overall, this study proves that a good lifestyle and diet will maintain everyone's health.
\end{abstract}

Keywords: Aerobic exercise, Obesity, Health, Physical Fitness.

\section{Introduction}

Health is very important because without good health, it will be difficult for every human being to carry out his daily activities. According to Griwijoyo et al. health is the foundation or basis for physical conditions that are indispensable for the success of carrying out work [1]. In addition to a lifestyle or lifestyle, the lack of understanding and awareness of Pertamina MOR IV Semarang employees to exercise also affects their health improvement. Even though the Pertamina MOR IV Semarang office has facilitated a fitness room, volleyball court, and basketball, which should have been maximized for sports. One of the health problems that may be experienced by employees is obesity. According to James W. P et al. obesity is an excessive or abnormal accumulation of fat that can interfere with health [2]. The main cause of obesity is an imbalance between energy intake and energy expenditure. Some of the risk factors that cause obesity are genetic factors, psychological factors, inappropriate lifestyle, wrong eating habits, stress, and other trigger factors [3]. According to Fadli and Sutisna, several impacts that occur in the long term due to obesity include the following: (1) Insulin resistance syndrome generally decreases the amount of insulin in the blood. As a result, it triggers Type 2 Diabetes Mellitus. (2) High Blood Pressure, obesity is one of the main causes affecting blood pressure. (3) Coronary Heart Disease, a disease that occurs due to narrowing of the coronary arteries. The risk of developing coronary heart disease increases with changes in the occurrence of excessive weight gain. (4) Respiratory disorders such as asthma, shortness of breath, slitting during sleep, and sleep apnea. This is due to the accumulation of excess fat 
under the diagram within the chest wall which stresses the lungs. (5) Joint disorders, which are often felt are low back pain and pain due to arthritis [4].

Based on the results of the survey and the facts in the field during observations found by the research team, the MOR IV area of the operational area of Central Java (Central Java) found more than $40 \%$ of employees are obese, which affects their physical fitness level. A person needs to strive to be healthy by having a lifestyle that supports health, such as by adopting a healthy eating style, paying attention to stress management problems, and having regular physical activity [5]. Therefore it is necessary to have a formula or program to solve this problem. Exercising regularly is a way to improve human health and fitness, especially aerobic exercise. Aerobic sports are sports activities with low to moderate that is carried out continuously, such as gymnastics, running, and cycling [6]. Energy metabolism in aerobic exercise runs through the burning of stored fat, carbohydrates, and a small portion (less than $5 \%$ ) of the breakdown of protein stores in the body to produce ATP. Apart from going through a regular exercise process, improving fitness or health must also be accompanied by adopting a healthy and nutritious diet, getting adequate and regular rest, and reducing excess stress because, in the end, it will affect your lifestyle and health. Many epidemiological studies have confirmed that physical activity can reduce the risk of various morbidity related to age or aging as well as the risk of mortality from any cause [7].

According to several previous studies, stated that moderate-intensity aerobic exercise can significantly reduce body fat and body weight [8]. Another opinion from Budiasih, she states that several factors that affect a person's physical fitness are knowing the lifestyle and diet [9]. From the above references, it can be seen that aerobic exercise has the opportunity to lose weight and burn fat significantly. Therefore, researchers are interested in researching aerobic exercise as a medium or treatment to lose weight for Pertamina MOR IV Semarang employees. The purpose of this study was to determine the effectiveness of aerobic exercise in losing weight and maintaining the health of Pertamina MOR IV Semarang employees.

\section{Methods}

The method used in this research is quantitative descriptive with instruments in the form of direct observation related to the progress of Pertamina employees in carrying out the weight loss program. The data collection technique used one group pre-test and post-test [10]. The results of the pre-test and post-test are used as comparative data and an indicator of the success of a study. The total number of participants used is 44 people provided that all participants are internal employees of Pertamina MOR IV Semarang and are willing to be participants in this research indicated by completing a willingness sheet to become a participant. The instrument used was a physical condition test using the Tecumseh test report, aerobic exercise, and jogging. The procedure for implementing the test in this study begins with socializing and understanding to employees regarding a healthy diet and proper diet, then mentoring aerobic exercise training to employees during the program.

The measurement process itself was carried out by the research team from UNNES, starting from measuring nutritional status to employee anthropometry. Assistance to respondents was carried out for 4 months with a predetermined training time (flexible) following the employee's busy level. Normally it is done in the afternoon, except for treatment or sports that are done on Saturdays and Sundays, usually in the morning. 


\section{Result and Discussion}

The first stage of this research is to measure each employee of Pertamina MOR IV Semarang to classify normal employees with obese employees. In general, from a total of 44 employees, the following results were obtained:

Table 1. Employee Health Status

\begin{tabular}{llll}
\hline Status & \multicolumn{2}{l}{ Employee Data } & Total \\
\cline { 2 - 3 } & Male & Female & \\
\hline Normal & 13 & 12 & 25 \\
Obesitas & 13 & 6 & 19 \\
Total Respondents & & & 44 \\
\hline
\end{tabular}

Table 1 above is the initial data that serves as a guideline or basis for conducting this research because the total respondents and the number of obese respondents, in general, are listed in it. The participant comparison ratio can be seen in Figure 1 below:

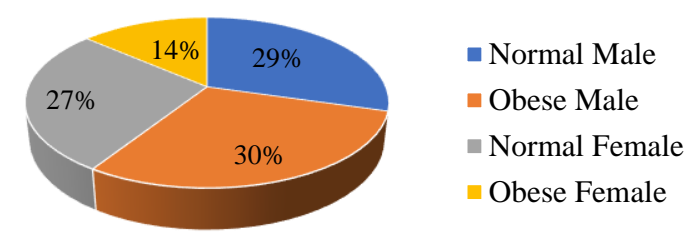

Fig. 1. Percentage of Pertamina MOR employee health status IV

The data in Figure 1 above states that a total of 44\% (13 men and 6 women) of employees are obese or overweight, while the rest, namely $56 \%$, are normal.

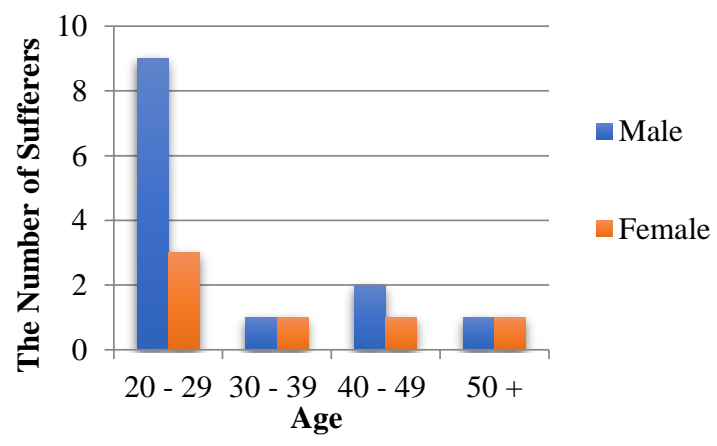

Fig. 2. Data on obesity respondents for Pertamina MOR IV Semarang employees

Based on the data in Figure 2, it can be seen that the average young employee between 20-29 years is obese. Based on the data above, the writer intends to provide treatment in the form of aerobic exercise as a method to lose weight for Pertamina MOR IV Semarang employees. Here are the treatments or training patterns: 
Table 2. Pertamina Employee Training Program

\begin{tabular}{|c|c|c|c|c|}
\hline No & $\begin{array}{c}\text { Treatment } \\
\text { Aerobics }\end{array}$ & $\begin{array}{c}\text { Intensity/ } \\
\text { Week }\end{array}$ & Day & $\begin{array}{c}\text { Duration/ } \\
\text { Minute }\end{array}$ \\
\hline 1 & Tecumseh & 2 & $\begin{array}{c}\text { Tuesday } \\
\text { Wednesday }\end{array}$ & $20-40$ \\
\hline 2 & Jogging & 1 & Saturday & 60 \\
\hline 3 & Gymnastics & 1 & Sunday & 60 \\
\hline
\end{tabular}

The intensity and time of training in table 2 above are made based on the level of busyness and schedule of Pertamina employees during the study. Therefore, it can change at any time according to the conditions and physical conditions of the employees. For this type of exercise, it can also be changed or combined.

Based on data from the Indonesian Minister of Health Regulation No. 8 of 2019 [11], states that the standard of energy or calorie needs of the human body for men is +-2500 and for women +-2000 , provided that they adjust their weight and height. Several studies suggest that women are more prone to obesity, such as the data on the prevalence of obesity according to the (Riskedas, 2013) increasing when compared to Riskesdas 2010. The male obesity rate in 2010 was around $15 \%$ and now it is $20 \%$. In women, the percentage is from $26 \%$ to $35 \%$ [12]. However, it does not rule out that men can also be obese with higher intensity, such as the case that researchers currently experience, it all depends on internal and external factors in each respondent starting from age, genes or heredity, level of physical activity, diet, lack of excessive rest and stress. Based on the researcher's analysis, the cause of the high level of obesity, especially in men at Pertamina MOR IV Semarang, is due to the high level of calories that enter the body, which is inversely proportional to the low level of physical activity undertaken so that the calories that enter the body are stored which will eventually become the main cause of obesity or overweight, especially when seen from Figure 2, it is clear that most obese people are aged 20-29 years, which if we look at the increasingly sophisticated era, young people are too late in technology and make them forget about sports.

According to the data in Figure 1 which contains the percentage of a total of 44 respondents including several influencing factors such as the value of the Body Mass Index (BMI), age, gender, health level (obesity), it is stated that the total respondents are obese as much as $44 \%$ of For the total sample, a formula is needed to solve these problems so that the level of health and performance of workers in related institutions can be increased. The treatment is carried out routinely in a week with the provisions of the Tecumseh, Jogging, and Gymnastics Tests, for the provision that the methodical test is carried out every morning before work by asking the agency for a little time to be given a little leeway. As time goes by, the test can be adjusted according to the needs and physical conditions of the respondent so as not to force it. However, in its implementation, it must also be balanced with a healthy diet, by paying attention to the levels of carbohydrates, fats, and proteins that enter the bodies of employees. Rosidji et al. stated that to lose weight a person needs to burn more calories than what enters the body [13]. The following are some data on the number of calories burned during aerobic exercise according Yuliastuti and Anggoro including (1) Static cycling: 520 calories per hour, (2) Stair-step machine (stair treadmill): 450 calories per hour, ( 3) Freestyle swimming: 450 calories per hour, (4) Jogging: 450 calories per hour [14].

For the Tecumseh data itself, it has the following results from a total of 19 respondents who are obese, 11 respondents experienced an increase with their respective levels where the 
highest increase at $71.43 \%$ was obtained by Respondent 1 , and the lowest increase was $2.04 \%$. obtained by Respondents 4 . While the other 8 respondents got results below the average starting from $0 \%$ by Respondents 14 and Respondents 16 (no increase) to the farthest below the average at a percentage of $-27.27 \%$, namely Respondents 13 . The purpose of this test is to measure a person's body's ability to adjust to the workload and recover from the work's origin or it can be called the body's aerobic ability [15]. The height of the bench, the rhythm of the ups and downs of the bench, the length of time going up and down the bench, and when to measure the pulse of recovery differentiate one test from another [16]. The measurement results are influenced by several factors including age, body condition, gender, and the readiness and seriousness of the respondent in carrying out the treatment. That means the aerobic treatment as mentioned above is proven to be able to lose weight with a structured and periodic implementation program according to the method developed by the researcher and balanced with a good lifestyle.

\section{Conclusion}

The results of this study found that 11 people $(25 \%)$ were effectively able to lose weight and maintain health. 19 people $(43.2 \%)$ were able to lose weight regularly, and 14 people $(31.8 \%)$ were able to maintain their normal condition. Overall, this study proves that aerobic exercise such as jogging, gymnastics, and Tecumseh tests can significantly reduce body weight coupled with a good lifestyle and diet to maintain everyone's health. The existence of continuous supervision and monitoring is expected to be able to maintain and maintain physical condition supported by routine aerobic exercises that are programmed.

\section{References}

[1] Griwijoyo S, Komariyah L, \& Kartinah N.T. (2007). Ilmu Kesehatan Olahraga (Sport Medicine). Pendidikan Olahraga.

[2] James W. P, Jackson-Leach R, Mhurchu C. N, Kalamara E, Shayeghi M, J. Rigby N, \& Rodgers A. (2000). Overweight and Obesity (High Body Mass Index). In Comparative Quantification of Health Risk. 498-598.

[3] Medawati A, Hadi H, \& Pramantara I D P. (2005). Hubungan Antara Asupan Energi, Asupan Lemak, dan Obesitas pada Remaja Siswa- Siswi SLTP di Kota Yogyakarta dan di Kabupaten Bantul. Jurnal Gizi Klinik Indonesia, I (3), 119-129.

[4] Fadli M, \& Sutisna H. (2017). Gambaran Nilai Kapasitas Vital Paru dan Tingkat Kebugaran pada Mahasiswa Perokok dan Bukan Perokok. Jurnal Kesehatan Andalas, 2 (3), 152-158.

[5] CB Corbin, RP Pangrazi, \& BD Franks. (2000). Definitions: Health, fitness and physical activity. President's Council on Physical Fitness and Sports Research Digest. 3 (9), 1-8.

[6] Irawan F A, Putra A A, \& Chuang L-R. (2019). Physical Fitness of Adolescent Smoker. Jurnal Kesehatan Masyarakat, 14 (3), 398-403.

[7] Angelica Anggunadi, \& Nora Sutarina. (2017, Januari). MANFAAT ACCELEROMETER UNTUK PENGUKURAN AKTIVITAS FISIK. Jurnal Olahraga Prestasi, 13 (1).

[8] Budiasih, U, Sulistyowati, E, Ambarwati, R, Supadi, J, \& Larasati, M. D. (2018). Efektifitas Senam Aerobik Intensitas Sedang Terhadap Persen Lemak Tubuh dan Berat Badan pada Mahasiswi Overweight di Jurusan Gizi Poltekes Kemenkes Semarang. Jurnal Riset Gizi, 6 (2), 79-84.

[9] Budiasih, K. (2011). Faktor- Faktor yang Mempengaruhi Kebugaran Jasmani Karyawan di PT. Amoco Mitsui Indonesia.

[10] Arikunto, S. (2010). Prosedur Penelitian. Jakarta: Rineka Cipta. 
[11] Kemenkes. (2019). Pemberdayaan Masyarakat Bidang Kesehatan.

[12] Riskedas. (2013). Riset Kesehatan Dasar.

[13] Rosidji C H, Isro'in L, \& Wahyuni N S. (2017). Differences in Risk Factor of Cardiovascular Disease Risk on Rural and Urban Population. Jurnal Kesehatan Masyarakat, 13 (1), 69-76.

[14] Yuliastuti, C, \& Anggoro, S. D. (2017). The Overview of The Elderly Lifestyle Profile in Surabaya. Jurnal Kesehatan Masyarakat,, 12 (2), 96-108.

[15] Rismaningtyas, K. (2016). Pengaruh Permaianan Bola Voli Mini Terhadap Peningkatan Kebugaran Jasmani Pecandu Narkoba. Journal of Physical Education, Sport, Health and Recreations, 5 (3), 118-119.

[16] Sudarno, S. (1992). Pendidikan Kesegaran Jasmani. 104. 